
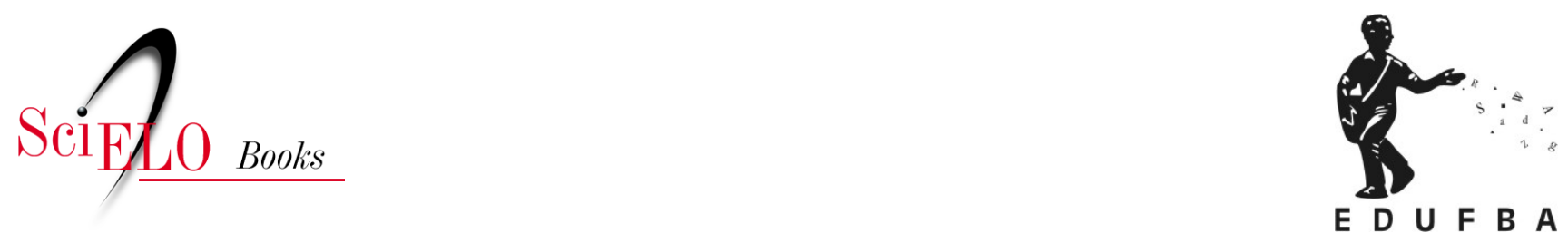

\title{
Reflexões \\ Dia do professor, dia de festa e celebração
}

\author{
Nelson De Luca Pretto
}

PRETTO, N.D.L. Dia do professor, dia de festa e celebração. In: Educações, culturas e hackers: escritos e reflexões [online]. Salvador: EDUFBA, 2017, pp. 181-183. ISBN: 978-85-232-2019-8.

https://doi.org/10.7476/9788523220198.0049.

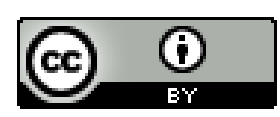

All the contents of this work, except where otherwise noted, is licensed under a Creative Commons Attribution $\underline{4.0 \text { International license. }}$

Todo o conteúdo deste trabalho, exceto quando houver ressalva, é publicado sob a licença Creative Commons Atribição 4.0. 


\section{Dia do professor, dia de festa e celebração}

Em 24 de agosto de 1974, tive minha primeira carteira assinada como professor. A escola era uma daquelas conhecidas, na Bahia de ontem, como "fábrica" e ficava no bairro Nazaré, bem pertinho do tradicional e público Colégio Severino Vieira. Depois daquela primeira experiência (quase traumática!) como professor daquela "espécie" de escola, não parei mais de atuar na educação. Trabalhei como professor em um bom número de colégios em Salvador e também em Feira de Santana.

Antes disso, já havia sido professor de Geografia, no antigo Curso Supletivo, no Colégio Antonio Vieira, com meus 16/17 anos, ao tempo em que também participava de uma experiência de educação de adultos em um centro comunitário, em Cosme de Farias, utilizando o método Paulo Freire. Vivi a riqueza de dar aulas para pessoas de mais de 60 anos, num rico processo formativo. Após as aulas, nós, os jovens professores, íamos até a casa do padre que coordenava o projeto e lá papeávamos até tarde, tomando uma boa cachacinha. Eram conversas sobre o projeto e a realidade brasileira. Começava assim minha formação política e a peregrinação para a construção de uma sociedade justa. Nada fácil, até os dias de hoje.

Defendo, desde muito, que não basta ao professor ser um provedor de conteúdos. Ele tem que atuar politicamente, o que inclui uma forte presença na mídia. Sempre insisto nessa dimensão ativista e comunicativa, essa já considerada por Paulo Freire desde 1960. Mas ocupar os espaços da mídia não era - e não é! - fácil. Desde meus primeiros anos como professor e sindicalista, escrevia artigos sobre educação e fazia visitas ao Dr. Jorge Calmon - e à zelosa D. Zélia - para apresentar meus textos, à época, ainda datilografados, na expectativa de, passando pelo seu crivo, vê-los aqui em A Tarde. Meu primeiro artigo tratava do tema das mensalidades das escolas particulares. 
Quase todo mês de outubro, escrevo algo sobre a nossa profissão. Isso porque me parece fundamental trazer para os leitores uma compreensão maior sobre o nosso papel. Somos uma categoria muito desprestigiada.

Pesquisa realizada pela Organização para a Cooperação e Desenvolvimento Econômico (OCDE) (2014), em 44 países, indicava o Brasil nas piores colocações em termos de salário dos professores. Enquanto em Luxemburgo, o salário anual de um professor girava em torno de $60 \mathrm{mil}$ dólares, no Brasil, era de 10 mil e poucos dólares. A média, nos países pesquisados, era de 30 mil dólares anuais ( $\$ 12.500,00 /$ mês). O piso salarial foi uma grande vitória, mas diversos Estados não o respeitam e seguem pagando salários menores. A jornada de trabalho de professor é exaustiva, com muitas horas em sala de aula e, muitas vezes, por conta dos baixos salários, ele pula de colégio em colégio.

Nesse contexto, a nossa formação e a articulação política não podem ser negligenciadas, sendo fundamental a atuação sindical. Lutamos muito para retomar o Sindicato dos Professores no Estado da Bahia (SINPRO), nos anos 1978/1979. Fiz parte dessa luta, com orgulho. Tínhamos - e ainda temos - uma grande preocupação com questões cruciais para ter uma educação que atenda toda a população, que seja de qualidade, laica e gratuita, e que forme cidadãos plenos e não apenas consumidores, seja de produtos ou informações.

Assim, o sindicato, desde aquela época, passou a ser, de fato, nosso. Mas precisamos estar lá, no SINPRO e na Associação dos Professores Licenciados da Bahia (APLB), presentes de forma cotidiana. Há poucos dias, encerrou-se a Jornada Pedagógica do SINPRO. Foram poucos os professores participantes, se considerarmos o tamanho de nossa classe.

Insisto que um professor precisa ter uma boa formação, inicial e continuada, bom salário e adequadas condições de trabalho. Esse tripé é fundamental para promover a revolução que necessitamos na educação. Isso exige um professor de tempo integral, fixo em uma única escola, com tempo para interagir com os colegas, para estudar e preparar aulas, para, enfim, ser um autor e não um mero reprodutor das informações distribuídas pelos sistemas, seja ele público ou privado. 
Nossas lutas não são pequenas. Mas a alegria que sempre nos acompanha merece ser destacada e celebrada. Hoje comemoramos o Dia do Professor e nada melhor do que fazer isso com festa. Sim, porque para nós, professoras e professores, todo dia é dia de luta e de festa, pois a educação é, essencialmente, um ato de amor, um ato de solidariedade para com o outro. E isso não quer dizer que ser professor seja um sacerdócio. Somos profissionais que precisam ser respeitados e valorizados e isto não tem sido visto nas políticas públicas ao longo dos anos.

Como mencionei, nesses mais de 40 anos de vida como professor acumulei experiências vividas aqui e acolá. Algumas dessas histórias estão no livro Uma dobra no tempo - um memorial (quase) acadêmico, que lanço hoje no Palacete das Artes (Salvador) e, dia 26, na Feira do Livro da Universidade Estadual de Santa Cruz (UESC). Esse livro é publicado pela Editus, da UESC, que vem fazendo, junto com a Edufba, um belo trabalho, em política de acesso aberto.

Meu livro e alguns outros dessas duas editoras estarão hoje a noitinha no lançamento e, com o apoio do SINPRO, vamos celebrar o Dia do Professor, o nosso dia, com uma feira de livros, um show de Chirlei Dutra e com o também lançamento do livro Projeto UCA: entusiasmos e desencantos de uma politica pública, resultante de nossas pesquisas na academia, organizado pelas colegas professoras Elisa Quartiero, Maria Helena Bonilla e Monica Fantin.

Venham a essa festa, afinal, no cotidiano laboral, sabemos muito bem lutar, mas também festejar. E uma boa luta é aquela que fazemos com alegria, mesmo porque trabalhamos para a construção de um mundo justo, solidário e também feliz. Salve o Dia do Professor!

Esse texto foi publicado, com modificações, no site Pensar Educação, em 16 de outubro, e no jornal A Tarde, Salvador, em 15 de outubro de 2015. 